HOW

Volume 28, Number 2, pages 159 - 178

https://doi.org/10.19183/how.28.2.619

HOW

\title{
Feminism in a Female Teacher's Discourse in an EFL Classroom
}

Feminismo en el discurso de una profesora en la enseñanza de inglés como lengua extranjera

\section{Mónica Patarroyo-Fonseca ${ }^{1}$}

\begin{abstract}
This research article on feminism gives an account of the interaction between a female teacher and her students at a public university in Tunja, Colombia. The study aims to evidence features of feminism within an English as a foreign language classroom by analyzing the transcriptions of the teacher's discourse using the Feminist Poststructuralist Discourse Analysis. As a result of the study, it can be stated that feminism is not determined by gender, but rather, it is an individual choice that is socially constructed and transmitted through power relationships. Findings suggest that being female or male does not guarantee having a definite position towards feminism; instead, it is mostly demarcated by the specific situations and circumstances that each individual experiences within a society.

Keywords: discourse analysis, feminism, feminist poststructuralist discourse analysis, interaction, power

\section{Resumen}

Este artículo de investigación acerca del feminismo da cuenta de la interacción entre una profesora y sus estudiantes, en una universidad pública, en Tunja, Colombia. El estudio busca evidenciar rasgos propios del feminismo dentro del salón de clase para el aprendizaje de inglés como lengua extranjera, analizando las transcripciones de su discurso por medio del Análisis del discurso Feminista y Poses-

She currently teaches general English to undergraduate students at Universidad Pedagógica y Tecnológica de

Colombia -UPTC. She holds an MA in Language Teaching, a specialization in Educational Management, and

a BA in Foreign Languages. Her research interests include discourse analysis and teaching materials.

monica.patarroyo@uptc.edu.co

ORCID ID: https://orcid.org/0000-0003-1916-7567

Received: October 1st, 2020. Accepted: April 23rd, 2021.

This article is licensed under a Creative Commons Attribution-Non-Commercial-No-Derivatives 4.0 International License. License Deed can be consulted at https://creativecommons.org/licenses/by-nc-nd/4.0
\end{abstract}


tructuralista. Como resultado del estudio, se puede afirmar que el feminismo no está determinado por el género en sí mismo, sino que es elección de cada individuo construida socialmente y transmitida por medio de relaciones de poder. Los resultados sugieren que ser de sexo femenino o masculino no garantiza tener una posición definida frente al feminismo, sino que dicha posición está más bien demarcada por situaciones y circunstancias específicas de cada individuo dentro de la sociedad.

Palabras clave: análisis del discurso, análisis del discurso feminista y posestructuralista feminismo, interacción, poder

\section{Introduction}

Teachers exert their power to guide learning (Richmond \& McCroskey, 1992), and power is revealed within their discourse. These powerful or powerless discourses have a significant impact because they strengthen or undermine the awareness of gender equity, and in this case, feminism. Currently, gender is vital in the EFL classroom since Norton (2000) claims that gender relations may affect the learning and teaching process. For instance, Goldberg (2016) considers that boys are disciplined more severely, provided with more praise and feedback, and encouraged to enroll in math and science courses; these pieces of evidence propose that learning is being affected and suggested because of the student's gender.

Based on the premise that gender affects the learning process, and that gendered discourses may be involuntary executed by the teacher in the EFL classroom, a study of that discourse becomes necessary to identify features about gendered issues. As a consequence, this research study focuses on recognizing specific discourse patterns related to feminism through the interactions in an EFL classroom and the tensions that emerge in the female teacher and her students' discourses. Based on this, two research questions were considered: (1) How is feminism evident through the interaction between the female teacher and her students in the language classroom? (2) What does the teacher's discourse reveal about her interactions with students in terms of feminism?

This research study took place at a public university in Tunja, Colombia, where the participants were a female English language teacher and the students of three undergraduate groups enrolled in English language courses. Data were collected from video recordings. Then the discourses were analyzed by using the Feminist Poststructuralist Discourse Analysis (FPDA). The findings from this research study led to the understanding that everyone has the power to choose feminism as a way of thinking (understanding it as the promotion of equal rights and respect between males and females). Society shapes what a person is and how she/he behaves, and teachers and students have the power to transform opinions and perceptions about gender inequality. 


\section{Review of the Literature}

\section{Gendered Discourses and Interaction}

Weatherall (2002) recognizes gender as a process built over time through intrapersonal and interpersonal relationships. It can be created, encouraged, and maintained through social structures. Connell (2009) describes gender as "a key dimension of personal life, social relations and culture" (p. 9). In other words, gender implies the relationship that a human being has with the environment that surrounds him/her, and this shapes the person; so, gender is molded by external factors.

Celce-Murcia and Olshtain (2000) and Baxter (2003) coincide in what discourse infers; one part relates to the structure and patterns, and the second implies the function, use, meaning, and practice, which is received by an audience or interlocutor and is shaped socially and ideologically. For example, students transmit at home what they learn in the classroom, and bring to the classroom what they learn at home. That is to say, gendered discourse is a social and ideological construction.

Castañeda-Peña (2008) summarizes gendered discourses when he considers that female teachers are "undermined by subtle discourses" (p. 314) in which boys resist female positions of power. In this current research study, gendered discourses entail a multifaceted version of the person that has been socially constructed and is able to transmit what his/her convictions, experiences, and thoughts are through power relationships.

Kurhila (2006) states that interaction is not just the controlled and manipulated linguistic contributions of the speaker to others. Instead, it is how people understand and are understood by others. Interaction is not only the interchange of linguistic patterns, but also implies aspects of communicating effectively and with a meaning, such as negotiating meanings and sharing and exchanging knowledge and thoughts about the world and the particularities of individuals. In Wells' opinion (1993), moves and turns in interaction are more significant than how large the units of discourse are. Interaction has the power to influence others through what individuals do and say. According to Wagner (1994) "interactions are reciprocal events that require at least two objects and two actions. Interaction occurs when these objects and events mutually influence one another" (p. 8).

The core of these constructs is to recognize that interaction occurs when two or more individuals exchange their verbal and non-verbal discourses. So, in order to transmit what is felt and thought, these discourses are, in most cases, influenced by ideologies and the society where the individual is immersed. If an individual has been exposed to gendered discourses that undermine the opposite point of view, this person will probably be influenced by such gendered discourses. 


\section{Power in Teacher Talk}

For this study, the teacher's power was centered on Richmond and McCroskey's (1992) considerations, namely: the role of the teacher involves a social influence, and the use of power is built into the job of a teacher. A teacher must have a considerable amount of power to conduct learning, and a teacher's power must be granted by the students. In Foucault's (1972) words, knowledge gives power to the teacher. Castañeda-Peña (2015) complements it by confirming that teachers occupy a privileged position of power due to their assigned official roles, wherein they assign turns of speaking, assessing, interrupting, etc. In addition, Dangel and Durden (2010) attest that the most powerful classroom tool to convey and construct meaning is teacher talk i.e., a teacher's work is mediated by power, and discourse becomes the means to transmit it.

In a critical view, the teacher in this study is not seen as the mere transmitter of knowledge, but also the transformer of thoughts, realities, and behaviors. For instance, if a teacher has the power to transmit positive attitudes and behaviors towards a certain situation, her/his students could transmit and reinforce that message. That is what Giroux (1988) called the transformative intellectual; the teacher has enough power to influence students through discourse.

\section{Feminism}

"One is not born but becomes a woman." Simone de Beauvoir, 1949

Beauvoir (1949) clearly stated what being a woman meant to her; women are molded by life experiences, not by the label/name per se. In this study, feminism is addressed as the position of each individual in the language classroom who seeks the promotion of equal rights for both females and males. It is an egalitarian position regarding women, and it can be accepted, respected, and promoted equally by males and females.

According to Mills (2017), the feminist movements took their form in three main waves. The first is predominately associated with women's suffrage in the US and Western Europe.

162 The second is identified with the political and social change that took place in the 1960s regarding a reaction against sexual discrimination and the widespread promotion of equal opportunities for both sexes. The third refers to the deconstruction of gender identities and certain relations within specific communities. The most recent wave incorporates constructivist principles and post-structuralist feminism. Mills formulates six aspects in the third wave that describe the diversity and multiplicity of women's identities:

- The performative rather than the essentialist nature of gender. 
- A focus upon context-specific gender issues rather than generalized questions.

- The importance of co-construction.

- Power not as a possession, but as flowing omnidirectionally in a web-like fashion.

- An emphasis upon notions of female resistance.

- A reinterpretation of stereotyped subject positions rather than notions of struggle against the subordination of women.

Feminism in Colombia has had a short history in comparison with other countries. Until 1931, women were not allowed to receive salaries or they received less salary than men, even if they worked at equal tasks as the men (Cabal \& Motta, 2005). In the 60's, one factor that influenced the appearance of feminism was the fact that women started to wear pants at church, even if the bishop demanded the use of elegant dresses. Also, women started to mobilize, work in markets, attend classes at a university in and outside Colombia (in the United States and Europe, especially postgraduate studies). As a consequence, three main scenes emerged: leftist parties and labor unions, public and private universities, and small feminist groups. In the 80 's, action and theory took place in which research was used to make visible critical aspects about feminism in public and private sectors.

Feminism both in Colombia and worldwide has sought visibility throughout time. Feminism in the ELT field cannot escape from it either, since the language classroom becomes an exemplary place to convey what humans are and think. In that sense, Mojica and Castañeda-Peña (2017) claim that language teachers should be aware of their possible gendered discourses and power issues since "this may help or hinder learning opportunities, language access, and meanings that students may learn about gender representations" (p. 140). That is to say, that the teacher's discourse has the ability to strengthen or weaken her/ his students' learning process.

The abovementioned theoretical constructs reveal the implications of the teacher's and the students' verbal and non-verbal discourses in the EFL classroom. For this reason, this research study seeks to understand the discourse of a female teacher and her students in terms of feminism, where the medium is the learning and use of EFL, whereby it becomes the vehicle to transmit equality, tolerance, and respect towards others.

\section{Method}

\section{Setting and Participants}

This research study took place at a public university in Tunja, Colombia, where its students are socially, educationally, politically, and religiously diverse. The International 
Languages Institute of the university is in charge of providing general English language courses for undergraduate students. The participating students belonged to three different English language courses. The reasons to select these groups were because they engaged in respectful, natural, spontaneous, and genuine communication with the teacher.

The students voluntarily decided to take part in the study after being informed about the nature of the project and the use of video recordings. They agreed by signing a consent form. The number of participants was as follows: Group 1=24, Group 2=28, and Group $3=22$ (total $=74$, women $=44$, men $=30)$. Their ages ranged from 16 to 19 years old.

The teacher is in her twenties, has worked at the university for 3 years, and holds a bachelor's degree in foreign languages. She was in charge of six undergraduate program groups. The teacher decided to participate in the project voluntarily because, as a teacher, she understands that words have power. At the time of the study, she was also a candidate for a master's degree in language teaching.

\section{Research Design}

As this study focuses on analyzing discourses, qualitative research suits its characteristics. Qualitative research is devoted to developing an understanding of human systems, small or large (Savenye \& Robinson, 1996). The method for collecting data is from participation in the setting (Marshall \& Rossman, 1999). The research approach is that of a descriptive and interpretative study, in which the first part focuses on the description of the speech form or the tangible aspect of the interaction, and the second part attempts to unveil the discourse implications by comprehending and analyzing its nature.

\section{Data Collection Instruments and Analysis}

The main instrument used to collect data was video recordings, supported by theoretical background. The video recordings show the interaction between the teacher and the students in the classroom and serve as access to primary data. They capture the daily life of the group under study (Marshall \& Rossman, 1999).

164 The process of video recordings started with the pilot stage, the purpose of which was, on the one hand, to prevent technical problems (sound, image, volume, etc.), and on the other, to look for the best place to set up the video camera in the three classrooms. In this stage, participants got used to the camera because it became part of the environment. In the second stage, "real" video recording started. This process took two and a half months (twenty-five video recordings were collected and organized by video number, group, and date). The third stage was that of observation which involved focusing on aspects such as words and gestures. Then, words related to the object of the study were written in the 
form of notes and the relevant parts of the video were fully transcribed, using discourse transcription conventions (Bartlett, 2014). The process for gathering data is shown in Figure 1 below.

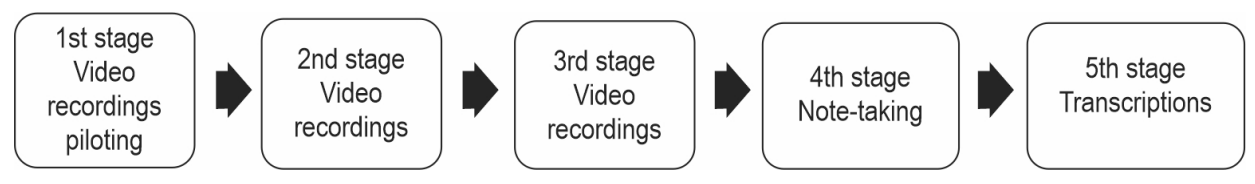

Figure 1. Data Collection Process

In terms of data analysis, the FPDA proposed by Baxter (2003) was employed. FPDA consists of identifying certain patterns that evidenced the presence of feminism through the interaction between the teacher and the students. Baxter (2008) defines FPDA as "an approach to analyzing intertextualized discourses in spoken interaction and other types of text $[\ldots]$. The feminist perspective on poststructuralist discourse analysis considers gender differentiation to be a dominant discourse among competing discourses when analyzing all types of text" (p. 245). In other words, FPDA considers how speakers negotiate positions, meanings, and power through discourses in enunciation contexts (Baxter, 2003).

FPDA has two distinct dimensions: it is post-structuralist (practices that shape the object) and feminist (gender equality). According to Baxter (2008), the FPDA approaches micro-analysis functions through two main levels or procedures: denotative and connotative. The first level attempts to describe the verbal and non-verbal interactions of a social group, that is, a description of events. The second level aims to interpret the data according to how speakers are continually positioning themselves in terms of power, based on competitive and intertextualized discourses.

In the first stage of data analysis, examples of feminism began to be identified in the transcriptions and were recorded using a color-coding system. Baxter (2008) terms these as 'significant moments' in the discourse. These colored patterns were placed in a matrix of three sections (excerpts-topics-theory). The matrix was created according to the consolidation of the data and the relation with theory from similar studies in order to comply with the parameters of validity and reliability. At this point, a number of common patterns (topics) started to emerge.

At the end of that process, a vertical matrix had been formed. Afterward, a fourth column, called memos, was added. This column was intended to narrow down the previously identified topics. Categories emerged from common features within the memos. Later, a process of denotative and connotative analysis took place in each of the chosen excerpts. 
The first part consisted of making a description of the verbal and non-verbal discourses.

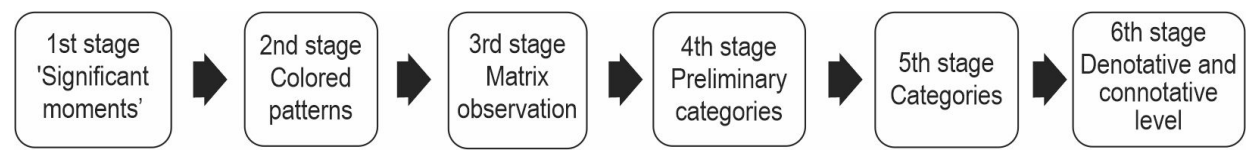

Figure 2. Data Analysis Process

The second part was done by analyzing the nature of those discourses. The process of data analysis is shown in Figure 2 below.

Likewise, it is imperative to clarify that the trustworthiness of this data analysis depends on the following notions:

- In a post-structuralist approach to discourse analysis, it is in the act of self-reflexivity that the connection can be made explicitly between 'what is being analyzed' and 'how it is being analyzed' (Baxter, 2003).

- Discourse analysis is not taken as a discipline, but as a systematic, rigorous way of suggesting answers to research questions posed in and across different disciplines throughout the humanities and social sciences (Johnstone, 2008).

Bearing these notions in mind, and following the process of analysis, two categories emerged: power reflecting gender equity and social norms shaping feminism.

\section{Findings}

The findings of this research study emerge in two major categories: power reflecting gender equity and social norms shaping feminism. The first one summarizes what Foucault (1972), Richmond and McCroskey (1992), Dangel and Durden (2010) and Castañeda-Peña (2015) consider in terms of power, in which the language teacher owns the power to share knowledge, influence, and shape her students through discourse. The second category reflects the fact that society is the tree that accompanies and allows people to choose their favorite and most convenient branch. In words of Beauvoir (1949), Mills (2017), and Mojica

166 and Castañeda-Peña (2017), feminism is shaped by society and is demonstrated in peoples' discourses. Feminism is not born necessarily from a female person; rather, feminism is for everybody (Hooks (2000).

\section{Power Reflecting Gender Equity}

This category emerges from the fact that power is always present in the EFL classroom and, most of the time, power is used to show and promote gender equity, either by the 
teacher or the students. For instance, by addressing her male and female students in the same manner, the teacher is promoting gender equity through the power that she possesses in the EFL classroom. Power is visible throughout the teacher's and students' discourses.

The excerpts below and their corresponding analysis are presented first at a denotative level, followed by the connotative level. The excerpts are based on the Transcription Conventions by Bartlett (2014) (See Annex 1).

Excerpt 1 illustrates the first attempt at finding a feminist position in the female language teacher. It displays a conversation (open questions and answers) about "meeting someone new".

\section{Excerpt 1.}

28. S2 (F): the last time (.) I met someone new was on vacation

29. T: $\quad$ on vacation (.) ok (.) second question (.) where did you meet them or her or him

30. S2 (F): in Rondón

[Transcription \#1. Group 1 - Mar 29 $9^{\text {th }}$ ]

In line 28 , the female student is answering the teacher regarding a specific question. In line 29, the teacher reinforces the student's answer, and decides to ask the same student a second question. It can be inferred that the teacher keeps control of the interaction, in which she uses the language to ask questions, and the student uses it as a vehicle to say something that she has experienced in her life.

At the connotative level, the use of the terms "them or her or him" indicate that the teacher's discourse does not mention one kind of person that her students might meet. She considers that meeting someone new may imply a man, woman, group, or a nonconforming person. This idea matches what feminists look for; the same rights, importance, and conditions for women and men, regardless of the context. Based on Hooks (2000), feminism is seen as a movement founded on gender equality, which promotes justice. In Excerpt 1, the discourse of the teacher does not evidence a gendered tendency, because she does not favor any gender per se. There is no obvious sign of using discourse to favor males or females, but rather her discourse promotes an egalitarian position towards gender. Excerpt 2 evidences a feminist position, too; but this time, it comes from two male students. The teacher is promoting the reading of an established conversation.

\section{Excerpt 2.}

109. T: conversation number two (0.3) someone raised a hand over there (.) Camila (.) who accompanies Camila $\downarrow$ \# two male students raise their hands at the same time\# [Transcription \#1. Group 1- Mar 29 ${ }^{\text {th }}$ ] 
In line 109, the teacher is calling for volunteers for the next conversation. While the teacher is waiting for a volunteer, a female student raises her hand. However, the teacher keeps asking for volunteer participation. The teacher uses the term 'accompany' to let her female student know that she would not have to do the activity alone. In response to her request, two male students raise their hands simultaneously. They do not hesitate, as their reaction is immediate. This fact shows that the male students are interested in supporting their female classmate.

At the connotative level, regarding the female teacher's discourse, when she asks "who accompanies Camila?", the teacher promotes equal participation from her students; she is not favoring any gender, but giving them the opportunity to be part of the class activity. This analysis matches what Holmes (1992) states when saying that "a dominant discourse of gender differentiation tends to construct 'men as more willing than women to contribute in public or formal contexts' " (p. 132). The male students seem to be more eager to support this female classmate than the other female classmates were.

The next excerpt has radically changed the previous course, since it reveals a nonfeminist position in the teacher's discourse. Some instructions are being read to complete a task.

\section{Excerpt 3.}

130. T: Yes (.) ok (.) student A introduces himself (.) student B introduces himself and ask questions (.) student $\mathrm{A}$ answers those questions and he can ask again (.) and so on

[Transcription \#1. Group 1- Mar 29 $9^{\text {th }}$ ]

In Excerpt 3, the teacher is giving instructions about an activity. She is showing an example of how the activity is going to work. The teacher does not use the students' names but letters of the alphabet instead, so she does not specify whether the student is male or female. It is demonstrated that the conversation has to be carried out by two people. However, there is a clear tendency to refer only to males by using the words "he" and "himself" throughout the intervention.

It can be inferred that the teacher omits the possibility of considering females as part of the instruction. According to Snyder (2008), feminism "creates conditions of freedom, equality, justice, and self-actualization for all people" (p. 192). It would appear that the teacher is not promoting gender equality in this situation. This is the kind of discourse that perpetuates females to remain hidden within certain formal and informal contexts. In consequence, these seem to be "right, common, and correct patterns" over time. However, as Baxter (2003) explains, people can recognize, take up or resist postures. 
Excerpt 4 exhibits "shared power" among the classroom agents. This instruction is given in the beginning of the class.

\section{Excerpt 4.}

01. T: good morning everyone (.) today you will be the teachers (0.2) I will divide you into groups and you will present the topics from the workbook

[Transcription \# 5. Group $2-\operatorname{Apr} 7^{\text {th }}$ ]

In Excerpt 4, the denotative level shows that the teacher wants to give power to her students. First, the teacher formally greets her students and, from the beginning of the session, lets them know the plan for the class. She assigns a new role to her students, which consists of being the official presenters of an already learnt topic. She also mentions that she is going to divide the class into groups to carry out the planned activity, which consists of presenting certain topics from the workbook.

At the connotative level, the teacher changes roles. The students will become the teacher and vice versa. With her discourse, she is informing that even if she is the one with the power in the classroom, it can also be shared. Feminists aim to obtain equal rights and responsibilities for men and women. In this session, power will be exerted by the students. They will also have the responsibility of accomplishing a certain goal. In terms of the students' new responsibility and position of power, it can be said that they will feel important because they have control over the teacher and the other classmates.

The second part of this category is focused on the students' discourse through the interaction with the teacher. The following excerpt considers a position of power that cannot be executed by the student. The students are working in groups but one of them is chosen to explain the topic.

\section{Excerpt 5.}

13. S3 (F): just me $\downarrow$ ((she raises her eyebrows and lowers her voice)) \#the female student seems nervous and looks around\#

14. T: $\quad$ yes (.) but you have a group that can help you

[Transcription \# 5. Group $3-$ Apr $7^{\text {th }}$ ]

In line 13 , it is evident that the female student does not feel comfortable about having all the power and the responsibility of having to complete a classroom task on her own, since she muttered: "Just me?" The tone she uses denotes a certain fear regarding what she has to 
do. In line 14, the teacher confirms that she has to do the activity alone, but she can count on her class group to support her.

In terms of the teacher's discourse, it is manifested that she understands her student's fear by letting her know about that; first, she considers her to be capable of accomplishing the task, and second, even if she cannot do it, the female student has a group to support her. Apparently, the student cannot handle the acquired position of power. Concerning Castañeda-Peña's (2008) statement, this female student undermines herself in terms of her role in the classroom. Furthermore, she is in a position of power because of her new role, but powerless because of her attitude towards it.

Different people in the same situation can experience power in different ways. This fact demonstrates that having a central role does not always mean having the ability to exert power. Walkerdine $(1998$, p. 65) points out that "individuals are powerless or powerful depending upon which discursive practices they enter as subject".

To sum up this category, power is always present in a classroom and this power is, most of the time, used to show equity. Sometimes, power belongs to the teacher or to the students depending on the activities that are taking place. On the one hand, even if the teacher has the power, this can be shared with others. At that point, the responsibility of having power is divided. On the other hand, if the student possesses the power, it does not mean that the student can take total advantage of it because he/she will not necessarily know how to use it.

When power is related to feminism, it gives the opportunity to express and shape the conceptions of others regarding its definition. For instance, if a feminist has the power to express in their immediate surroundings what feminism entails, this can bring about a new understanding of the concept. The immediate ambience/environment for teachers is the classroom. The classroom then becomes a place where respect and tolerance exist. Power can be used to allow people to understand that feminism does not just favor women, but men and women equally.

\section{Social Norms Shaping Feminism}

Feminism is concerned with the social norms that rule people's lives; society shapes 170 people's discourses. Fairclough (1992) and Baxter (2003) consider that discourse is formed by social practices and language is the vehicle to express it.

In the following excerpts, society plays an important role in the female teacher's verbal and non-verbal discourse, and it is analyzed at a denotative and connotative level. Excerpt 6 entails the teacher's distinctive version of herself in terms of what she has learnt from society, experience, etc. In this transcription, the teacher is guiding the reading of the material used in class. 


\section{Excerpt 6.}

36. S3 (F): \#the student touches her chin\# we talked about ((unintelligible))

37. T: ok thank you (.) $\mathrm{mmm}$ ok (.) David would you mind reading the part of the vocabulary $\boldsymbol{\uparrow}$ plea:::se

[Transcription \#1. Group 1- Mar 29]

In line 36, the female student is thinking about the answer that she is going to give the teacher. This can be deduced by the way she uses her hand to touch her chin. After thinking about it, she finally comes up with an answer. In line 37, the teacher reinforces her answer by saying "ok". In addition, she is thankful for the answer to her question. Next, the teacher has to choose another person to participate. She calls on a male student and asks him, in a polite way, to follow her instructions. She finishes her intervention by saying "please". Regarding the teacher's discourse, it sounds very polite and respectful.

In Excerpt 6 above, the female teacher tends to be very respectful and polite towards her students. She says "thank you", "would you mind", and "please" in one single sentence, which demonstrates that politeness is important for her, independently of whom she is addressing. However, this cordial trait is not a result of belonging to a determined gender, but depends on one's own idiosyncratic version in relation to the attitudes of the society (Stoller, 1994). In her discourse, she can promote a feminist viewpoint, in which she demonstrates that being respectful and polite is necessary with all people.

Next excerpt, both the teacher and the female student are aware of the importance of tough matters in society, since they can be harmful or inappropriate if people are not prepared to respect and accept others' beliefs and political preferences.

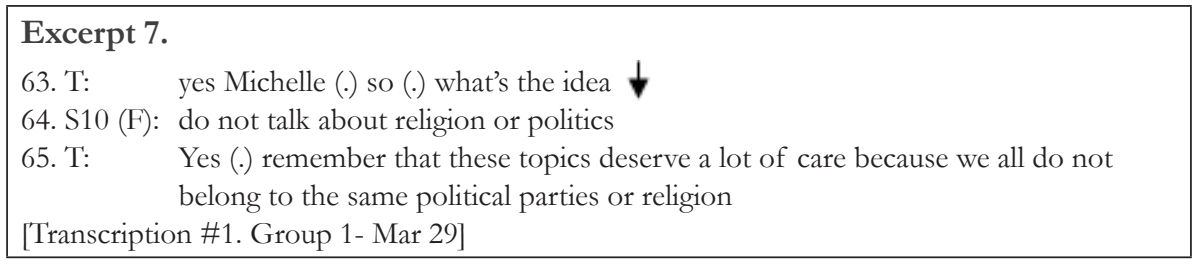

On the denotative level, the teacher approves what the female student is saying and, additionally, wants to know what the student had understood. In line 64, this female student comes up with a clear answer, in which she is conscious that topics such as politics and religion should be addressed with a lot of care. In line 65 , the teacher reinforces her student's position, and overtly states that certain topics, in certain circumstances and contexts, may be uncomfortable for some people. She places emphasis on this when saying the word 
'remember', implying that this should be mandatory for her students to comprehend and apply. She also includes herself as one of those who may not share the same views, but respects those of others, and for that reason, others should respect hers.

At the connotative level, the female student and the teacher fulfill their function as social agents through language. They use their discourses to position themselves as women and human beings who respect differences. Consequently, they transmit this message to the rest of the class. The teacher's position shows that social aspects must be constructed within the classroom. The teacher has the right and duty to promote equity in all senses. Society tends to judge differences wrongly, and there is no room for other people's opinions and perspectives. The social role that the teacher plays is very meaningful in terms of promoting respect in and outside the classroom.

The following excerpt also demonstrates the attitude of a male student regarding respect. This student has probably brought to the classroom what he has learnt at home. The teacher is mediating the sequence of a reading activity.

\section{Excerpt 8.}

61. S8 (M): me (0.3) sorry (.) I didn't listen to you

62. T: ok (.) the reading section which has the

63. S8 (M): [the art of conversation]

64. T: yeah

[Transcription \#3. Group 2- Mar 29 ${ }^{\text {th }}$ ]

In the preceding excerpt, in line 61 , the male student seems a little bit surprised when he is asked to do the reading, and for that reason, he apologizes because he did not hear the teacher's intervention, and he clarifies why he could not follow the instruction. In line 62, the teacher does not mind repeating to her student, although he was not listening to her. In fact, she says that it is 'ok' or that she does not have any problem. She waits for a second and repeats the instruction. While doing so, the male student realizes what he must do and completes the teacher's instruction. Finally, she confirms what he has to do.

At the connotative level, the perception of being socially shaped is confirmed in this excerpt, when this male student apologizes to the teacher in a polite way. This apology proves that this male student has formed his discourse from his own experience. The male student's discourse demonstrates that he respects her, as the teacher, as he would do with a male teacher in the same situation. In other words, this male student could be considered a feminist, since he applies equal rights and respect to everybody (Hooks, 2000). He is promoting feminism in his classroom because females and males deserve equal respect and politeness. In addition, the teacher shows herself to be an individual who can accept apologies from others, and not 
judge them. The act of apologizing is seen as good behavior that should be promoted in every context.

Excerpt 9, which is completely opposite to the previous one, confirms a non-respectful attitude towards the female teacher. The student is supposed to ask someone else a series of questions but he is not in the mood to do so.

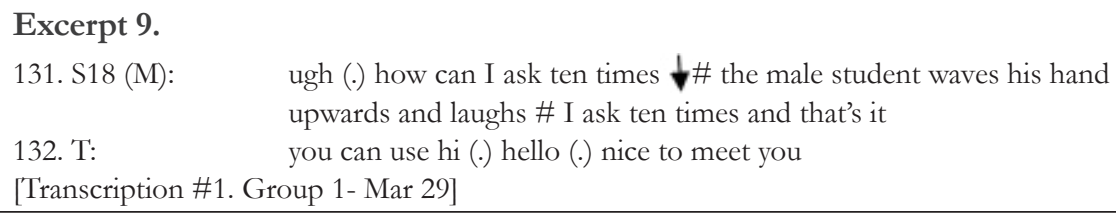

In line 131, the male student does not appear to be in agreement ("ugh") with something the teacher said. His discourse may not be appropriate for addressing the teacher, considering her role, but he does not seem to care. This male student also "speaks" with his body since he uses his hands to keep showing his position towards the instruction. Usually, in Colombia, waving the hand upwards means that the person does not care about what is being said, or does not agree with it. So, this non-verbal language demonstrates that he is not in the mood to do what the teacher has instructed. When he laughs, this implies that he finds the instruction to be amusing. In fact, he goes further by proposing his own instruction. In line 132, the teacher tries to reduce the impact of her instruction in response to the student's position by mentioning that simple utterances also count towards the activity that the students had to do.

At the connotative level, the student's intervention does not seem to be a discourse that promotes respect in the classroom. This is related to what Castañeda-Peña (2008) states, namely, "Female teachers and girl-teachers are seemingly undermined by subtle discourses in which boys resist and aim at suppressing female powerful positions" (p. 314). It is inferred that this male student behaves in the way he has learned from society. Fairclough (2013) asserts that social practices shape what individuals use in their language discourses. The student maintains that attitude and addresses a woman in whatever way he likes. If he behaves that way towards his teacher, which is likely the way he addresses other females. Also, he also seems to "mock" his teacher by trying to diminish her power. Castañeda-Peña (2008) states that masculine discourses sometimes ridicule feminine ones, by showing their opposition.

In excerpt 10, a non-respectful attitude towards the teacher and classmates is confirmed, this time by a female and a male student. This event occurs in the beginning of the session because students are starting to get the material to work in class. 


\section{Excerpt 10.}

19. T: (([A female student is giving money back from the copies to the students around all the classroom, and talking to them while the teacher is speaking. Also, a male student stands up and leaves the classroom to get a set of copies made]))

[Transcription \# 6. Group 2- Apr 26 ${ }^{\text {th }}$ ]

In this excerpt, even though it is the teacher's intervention, the non-verbal language of her students plays a significant role. While the teacher is addressing the class, this female student is distributing the copies. She is also talking to her classmates and does not seem to be paying attention to what the teacher is doing. In addition, when a male student realizes he does not have the copies and that he would not receive them from his female classmate, he decides to stand up and leave the classroom.

This excerpt shows how these two students, through non-verbal language, demonstrate that respect towards others is not important for them. It can be inferred that the class was divided into two groups: the students that were not paying attention because they did not have the material, and those who had the material and were trying to pay attention. The first group of students never asked for permission or gave an excuse for interrupting the class. These students do not conceive that respect must be extended to everybody, as Hooks (2000) noted from experience.

The previous excerpts elucidated that social norms are acquired by means of interacting with the people who surround us. People learn from others; people are not isolated parts of society. Humans learn both good and bad things, and it depends on each person what aspects they decide to take on and apply. People who are immersed in a language classroom do not escape from this fact; the teacher and the students reflect on what they have learned from society or their immediate place of interaction.

Based on the theoretical concepts and the categories emerging from this study, it is considered that the feminist side (teacher and students) was not always undermined by powerful male discourses, as most male students were eager to support their classmates and respect their teacher. Only a small number of students (males or females) did not take a

174 position of respecting the teacher and their classmates. However, having respectful and fairminded students can also affect others positively, and thus, a small change will occur in the classroom, at home, and in society. Teachers and students have the power to transform other people's opinions and perceptions about gender inequality. The key element is to transmit the sense of egalitarianism if possible, without attacking others but rather helping them to become aware of the situation. In terms of EFL learning, language becomes the vehicle to promote those little changes in the classroom; changes that will strengthen our students' behaviors to build a stronger society in terms of equity. 


\section{Conclusions and Pedagogical Implications}

The research questions that are intended to be answered are: (1) How is feminism evidenced through the interaction between the teacher and her students in the language classroom? (2) What does the teacher's discourse reveal about her interactions with students in terms of feminism? The first research question can be answered as follows: Feminism is evidenced through a discourse that promotes gender equity, a non-verbal language that considers everyone in the classroom as equals, respect towards others and their differences, and sharing power with those who do not usually have it within the classroom. Likewise, power is the key to impact our students' thoughts and behaviors towards feminism. The second question can be answered by understanding that the teacher changes her discourse by generally considering (in her verbal and non-verbal language) males and females to the same degree, and not giving more importance to one group or individual. The teacher's discourse visibly demonstrated that she tends to consider a feminist view in her role as teacher and person.

As a first conclusion, concerning feminism, it can be said that it is not an innate characteristic of all humans; it is shaped over time through lived experiences. For that reason, feminism is a way of thinking. Feminism then becomes a powerful tool in order to think and act differently. It allows the validation, through verbal and non-verbal discourse, that all humans must possess the same rights. In this research study, data analysis indicates that the female teacher promotes feminism since she encourages, in most cases, the participation of girls and boys, shares her power in the classroom, and tries to give the same importance to all her students. However, recognizing that she sometimes tends to favor the male side is valuable. Similarly, most female and male students evidence a feminist view and behavior since they respect their equals through their verbal and non-verbal discourses.

Second, male or female students do not shape themselves in terms of respecting others in the language classroom; they are shaped by the society that surrounds them and, based on that, they experience, think, and behave accordingly. Students bring to the EFL classroom what they have learned outside. The EFL classroom should then become the first place to use language as a means of social transformation, as a way to share opinions, and ideas, as well as be the perfect place to listen to diverse viewpoints in order to foster empathy.

In terms of interaction, the first category demonstrates that feminism is revealed through power, because it is through power that people have the opportunity to declare their thoughts, ideas, feelings, etc. Later, these ideas can be heard by a specific audience (EFL students), an audience that decides if what they have learned deserves understanding and action. For instance, an agent (teacher or student) that possesses power in a classroom can defend and promote feminism within the setting. Once the agent has stated their ideas clearly, they might influence and transform the perceptions of others. 
In terms of pedagogical implications, the teacher does not only teach a foreign language through her verbal and non-verbal discourse but also shares and serves as a model of respect for differences, becoming an agent of change that contributes to shaping her students' thoughts and behaviors to become better individuals in society. Language is the means of communication, but what is being communicated is more relevant.

Another pedagogical implication is that the female teacher might change her discourse in terms of equity since she is now conscious of its influence. Once she, he, they are knowledgeable about the issue, it is their responsibility and duty to make changes and generate a positive impact on the students using EFL. Henceforth, the bases of fairness are established.

\section{References}

Bartlett, T. (2014). Analyzing power in language: A practical guide. Routledge. https://doi. org/10.4324/9781315851938

Baxter, J. A. (2003). Positioning gender in discourse: A feminist methodology. Springer. https://doi. org/10.1057/9780230501263

Baxter, J. A. (2008). Feminist post-structuralist discourse analysis: A new theoretical and methodological approach? In K. Harrington, L. Litosseliti, H. Sauntson, \& J. Sunderland (Eds.), Gender and language research methodologies (pp. 243-255). Palgrave Macmillan.

Beauvoir, S. L. E. M. B. (1949). Le deuxieme sexe. Gallimard.

Cabal, L., \& Motta, C. (2005). Más allá del Derecho: Justicia y Género en América Latina. Siglo del hombre Editores.

Castañeda-Peña, H. (2008). Positioning masculinity and femininity in preschool EFL education. Signo y Pensamiento, 27(53), 314-326.

Castañeda-Peña, H. (2015). Classroom discourse analysis: Outlining the field. In W. Escobar \& H. Castañeda-Peña (Eds.), Discourse analysis applied to English language teaching in Colombian contexts: Theory and methods (pp. 21-43). Editorial Universidad El Bosque.

Celce-Murcia, M., \& Olshtain, E. (2000). Discourse and context in language teaching: A guide for language teachers. Cambridge University Press.

176 Connell, R. (2009). Gender: In world perspective (2 $2^{\text {nd }}$ ed.). Polity Press.

Dangel, J., \& Durden, T. (2010). The nature of teacher talk during small group activities. Elsevier.

Fairclough, N. (1992). Discourse and social change. Polity Press.

Fairclough, N. (2013). Critical discourse analysis: The critical study of language. Routledge. https://doi. org/10.4324/9781315834368

Foucault, M. (1972). The archaeology of knowledge and the discourse on language. Pantheon Books.

Giroux, H. (1988). Teachers as intellectuals: Towards a critical pedagogy of learning. Bergin and Garvey. 
Goldberg, S. (2016, August 24). Gender in the classroom. Today's Parent, p. 45.

Holmes, J. (1992). An introduction to sociolinguistics. Routledge.

Hooks, B. (2000). Feminism is for everybody: Passionate politics. Pluto Press.

Johnstone, B. (2008). Discourse analysis. Blackwell.

Kurhila, S. (2006). Second language interaction. John Benjamins Publishing Company. https://doi. org $/ 10.1075 /$ pbns. 145

Marshall, C., \& Rossman, G. (1999). Designing qualitative research. Sage Publications.

Mills, A. J. (2017). Studying the gendering of organizational culture over time: Concerns, issues, and strategies. In A. J. Mills (Ed.), Insights and research on the study of gender and intersectionality in international airline cultures (pp. 71-91). Emerald Publishing Limited. https://doi. org/10.1108/978-1-78714-545-020171005

Mojica, C. P., \& Castañeda-Peña, H. (2017). A learning experience of the gender perspective in English teaching contexts. Profile: Issues in Teachers' Professional Development, 19(1), 139-153. https://doi.org/10.15446/profile.v19n1.56209

Norton, B. (2000). Identity and language learning: Gender, ethnicity and educational change. Longman/ Pearson Education Limited.

Richmond, V., \& McCroskey, J. (1992). Power in the classroom: Communication, control and concern. Lawrence Erlbaum Associates.

Savenye, W., \& Robinson, R. (1996). Qualitative research issues and methods: An Introduction for educational technologists. In D. Jonassen (Ed.), Handbook of research for educational communication and technology (pp. 1045-1071). Macmillan.

Snyder, R. (2008). What is third-wave feminism? A new directions essay. Signs: Journal of Women in Culture and Society, 34(1), 175-196. http://www.jstor.org/stable/10.1086/588436

Stoller, R. (1994). Sex and gender: The development of masculinity and femininity. Routledge. https://doi. org/10.4324/9780429479915

Wagner, E. (1994). In support of a functional definition of interaction. The American Journal of Distance Education, 8(2), 6-26. https://doi.org/10.1080/08923649409526852

Walkerdine, V. (1998). Counting girls out: Girls and mathematics. Falmer Press. https://doi. org/10.4324/9780203209394

Weatherall, A. (2002). Gender, Language and Discourse. Routledge. https://doi. org/10.4324/9780203988817

Wells, G. (1993). Reevaluating the IRF sequence: A proposal for the articulation of theories of activity and discourse for the analysis of teaching and learning in the classroom. Linguistics and Education, 5(1), 1-37. https://doi.org/10.1016/S0898-5898(05)80001-4 


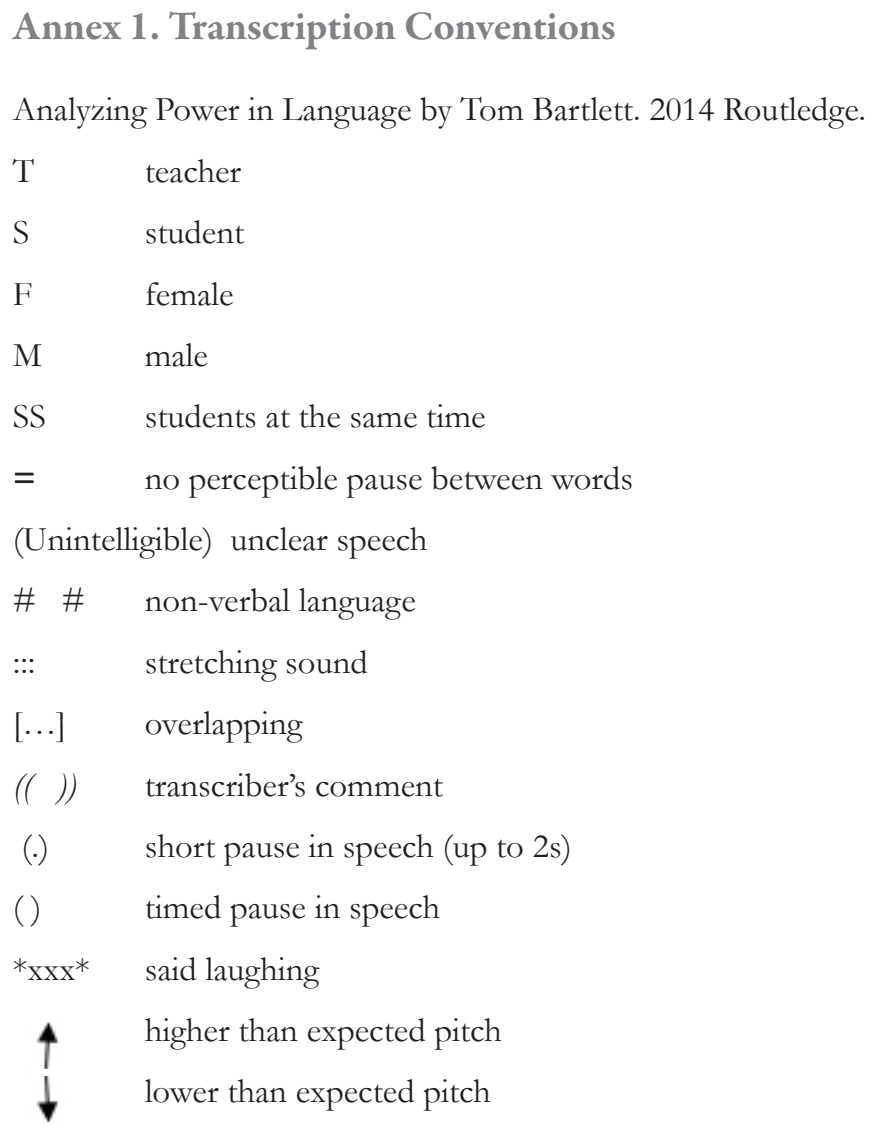

